\title{
Broiler chick performance and meat quality depending on the type of fat in feed mixtures
}

\author{
Ewa Świerczewska ${ }^{1}$, J. Mroczek ${ }^{2}$, J. Niemiec ${ }^{1}$, M. Słowiński ${ }^{2}$, \\ M. Jurczak ${ }^{3}$, Anna Siennicka ${ }^{1}$ and P. Kawka ${ }^{4}$
}

\author{
Warsaw Agricultural University \\ 'Department of Poultry Breeding \\ Przejazd 4, 05-840 Brwinów, Poland \\ ${ }^{2}$ Department of Food Technology of Animal Origin \\ Grochowska 2,03-849 Warsaw, Poland \\ ${ }^{3}$ Institute of Cattle Breeding and Dairy Science \\ Przejazd 4, 05-840 Brwinów, Poland \\ ${ }^{4}$ Institute of Genetics and Animal Breeding, Polish Academy of Sciences \\ Jastrzębiec, 05-551 Mroków, Poland
}

(Received 30 September 1996; accepted 19 August 1997)

\begin{abstract}
From the fourth week of life, 1200 ISA Vedetta chicks were fed with one of four feed mixtures with similar protein and energy contents, to which were added: $8.0 \%$ rape seeds (diet I), $4.0 \%$ lard (diet II), $5.5 \%$ by-product fat (diet III) or $3.5 \%$ sunflower oil (diet IV). The highest body weight achived broilers fed diets with lard $(\mathrm{P} \leqslant 0.01)$; feed utilization per $\mathrm{kg}$ gain was the best in this group too.

The cholesterol content of meat from broilers receiving the sunflower oil-containing diet was the lowest, and the linolenic and linoleic acid contents in breast and thigh meat were the highest in chickens fed the rape seeds-containing diet.
\end{abstract}

KEY WORDS: broiler chickens, fats, meat quality, fatty acids

\section{INTRODUCTION}

Fats used in the feeding of poultry are a source of energy and essential fatty acids, take part in the transport of lipophilic vitamins, make feeds less powdery and improve their flavour (Adamski and Gornowič,1993; Villalbi et al., 1993; Niemiec et al., 1996). Broiler feed mixtures contain animal or vegetable fats. The 
utilization of these fats depends on the age of the chickens, the composition of the feed, and on the quality and amount of added fat (Hulan et al., 1984). Ketels et al. (1987) report that increasing the amount of beef fat in diets adversely affects feed utilization, and long-chain fatty acids from lard are utilized to a lesser extent than from soyabean oil.

The objective of this study was to examine if the supplementation of broiler chicken feed mixtures with high energy additives such as rape seeds, lard, by-product fat and sunflower oil, influences on broiler performance, quality and technological parameters of meat.

\section{MATERIAL AND METHODS}

The expcriment was carried out on 1200 ISA Vedetta chickens divided into 4 groups. Up to the age of three weeks, all of the chickens were fed the same starter feed, from week 4 to 7 , balanced grower mixtures that differed in the composition of high-energy components (Table 1):

diet I: $\quad 8.0 \%$ rape seeds 00 ,

diet II: $4.0 \%$ lard,

diet III: 5.5 by-product fat (by-product of gelatin production),

diet IV: $3.50 \%$ sunflower oil.

The chickens were weighted at 3 and 7 wecks of age, feed intake and mortality were recorded. $\Lambda$ fter completion of the experiment, the broilers were starved for $12 \mathrm{~h}$, then 10 malels and 10 femals from each group were slaughtered and carcass analysis was carried out. Dressing percentage, and the content of breast and thigh muscles, edible giblets and abdominal fat pad in the carcass were determined.

Quality assessment was carried out on the breast and thigh muscles and abdominal fat pad of six chickens from each group. The basic chemical composition of breast and thigh meat was determined by conventional methods, $\mathrm{pH}$ according to standard procedure (PN-77/A82058), water holding capacity by the centrifuge method modified by Wierbicki et al. (1962), thermal leakage following heat processing according to Baryłko-Pikielna et al. (1973), heme pigment content using the acidified acetone extraction method (Hornsey, 1956).

The cholesterol content was determined according to Rutkowski and Krygier (1979), using the method of extracting lipids and nonsaponifying substances with a chloroform-methanol mixture with the addition of cholestan as the internal standard.

Tissue and abdominal fat pad lipids were extracted with a mixture of chloroform and methanol, after extraction glycerides were saponified with a methanol solution of $\mathrm{KOH}$ and esterified in the presence of tionyl chloride. The 
TABLE ]

Composition of dicts

\begin{tabular}{lcccc}
\hline \multirow{2}{*}{ Componcnts } & \multicolumn{4}{c}{ Diets } \\
\cline { 2 - 5 } & rape seeds & lard & by-product fat & sunflower oil \\
\hline Ground maize & 6.0 & 16.0 & 16.0 & 16.0 \\
Ground wheat & 39.7 & 41.2 & 39.7 & 41.7 \\
Soyabean oilmeal, 46\% & 18.0 & 20.5 & 20.5 & 20.5 \\
Whcat bran & 10.0 & 10.0 & 10.0 & 10.0 \\
Rape seeds "00" & 8.0 & - & - & - \\
Lard & - & 4.0 & - & - \\
Sunflower oil & - & - & - & 3.5 \\
By-product fat & - & - & 5.5 & - \\
Mcat mcal, 63\% & 5.0 & 5.0 & 5.0 & 5.0 \\
Calcium phosphate & 2.0 & 2.0 & 2.0 & 2.0 \\
DL-Methionine premix & 0.3 & 0.3 & 0.3 & 0.3 \\
NaCl & 0.3 & 0.3 & 0.3 & 0.3 \\
Mineral-vitamin premix & 0.7 & 0.7 & 0.7 & 0.7 \\
Chemical composition, \% & & & & \\
$\quad$ crude protein & 19.43 & 19.13 & 19.00 & 19.18 \\
$\quad$ lysine & 1.09 & 1.07 & 1.06 & 1.07 \\
$\quad$ methioninc + cystinc & 0.81 & 0.82 & 0.81 & 0.82 \\
Cat & 1.16 & 1.16 & 1.15 & 1.16 \\
$\quad$ available P & 0.68 & 0.67 & 0.67 & 0.67 \\
crude fat & 2.96 & 6.53 & 7.96 & 6.17 \\
linoleic acid & 0.59 & 0.92 & 0.59 & 0.60 \\
Metabolisable energy, MJ/kg & 12.28 & 12.67 & 12.59 & 12.63 \\
\hline
\end{tabular}

fatty acid composition was analyzed by gas chromatography (HP 5890), the acid value, peroxide value, TBA index and melting temperature of fat were determined according to the method of Rutkowski and Krygier (1979).

Sensory analysis was carried out individually on boiled meat and bouillon. The meat test included: flavour, taste and consistency, bouillons were evaluated according to their clarity, flavour and taste. Every sample and characteristics was graded using a 5 degree scoring system ( 5 - the best).

The data on body weight and dressing percentage were subjected to variance analysis and the Duncan test. The data on meat quality were analyzed using the least squares model employing Harvey multifactorial analysis.

\section{RESULTS AND DISCUSSION}

The body weight of the chickens in the period preceding the experiment (i.e. up to 3 weeks) differed significantly $(P \leqslant 0.01)$ among groups (Table 2$)$. At 7 weeks, 
TABLE 2

Performance of broilers

\begin{tabular}{|c|c|c|c|c|c|c|c|}
\hline \multirow[t]{3}{*}{ Group } & \multirow[t]{3}{*}{ Source of fat } & \multicolumn{2}{|c|}{ Body weight. $\mathrm{g}$} & \multicolumn{2}{|c|}{$\begin{array}{c}\text { Feed utilization } \\
\mathrm{kg} / 1 \mathrm{~kg} \text { body weight }\end{array}$} & \multicolumn{2}{|c|}{ Mortality, \% } \\
\hline & & \multicolumn{2}{|c|}{ weeks } & \multicolumn{2}{|c|}{ weeks } & \multicolumn{2}{|c|}{ weeks } \\
\hline & & 3 & 7 & $0-3$ & $0-7$ & $0-3$ & $0-7$ \\
\hline I & Rape seeds "00" & $579^{\wedge}$ & $1966^{\wedge}$ & 1.55 & 2.42 & 2.0 & 5.6 \\
\hline II & Lard & $556^{\mathrm{A}}$ & $2106^{15}$ & 0.92 & 2.25 & 2.0 & 8.3 \\
\hline III & By-product fat & $553^{\mathrm{B}}$ & $2043^{\mathrm{C}}$ & 1.57 & 2.29 & 3.2 & 8.0 \\
\hline IV & Sunflower fat & $590^{\mathrm{A}}$ & $1997^{\mathrm{A}}$ & 1.49 & 2.43 & 1.0 & 4.3 \\
\hline & SEM & 4.719 & 14.114 & & & & \\
\hline
\end{tabular}

$\mathrm{A}, \mathrm{B}, \mathrm{C}-\mathrm{P}<0.01$

a highly significant difference in body weight depending on the fat added to the feed mixture was found (Niemiec et al., 1996). The highest weight $(\mathrm{P}<0.01)$ was achieved in the group fed the diet with lard. Similarly in the studies of Farrell (1978), chickens utilized feed containing animal fat better than that with vegetable oil, while Blanch and Grashorn (1995) did not find significant differences in the body weight of broilers fed diets supplemented with animal fat, soyabean oil, rape seed oil, linseed oil, or sunflower oil.

Feed utilization did not differ significantly among groups (Table 2).

Chick mortality equaled 4.3 and $5.6 \%$ in the groups receiving sunflower oil and rape seeds, respectively, and 8.3 and $8.0 \%$, in the groups fed mixtures containing lard and by-product fat, respectively.

The dressing percentage of broilers fed the sunflower oil-containing feed was the highest $(71.4 \%)$, and differed significantly only from the dressing percentage in the group fed by-product fat $(69.5 \%)$ (Table 3 ). The percentage of abdominal fat pad was lower $(P \leqslant 0.01)$ in the carcasses of chickens fed the diet with rape seeds than in the remaining groups.

TABLE 3

Slaughter results, \%

\begin{tabular}{lccccccc}
\hline & \multirow{7}{c}{$\begin{array}{c}\text { Dressing percentage } \\
\text { without giblets }\end{array}$} & $\begin{array}{c}\text { breast } \\
\text { muscle }\end{array}$ & $\begin{array}{c}\text { thigh } \\
\text { muscle }\end{array}$ & liver & heart & gizzard & $\begin{array}{c}\text { abdominat } \\
\text { fat pad }\end{array}$ \\
\cline { 3 - 8 } & $69.0^{\mathrm{AB}}$ & 21.0 & $22.9^{\mathrm{A}}$ & $3.16^{\mathrm{AB}}$ & 0.63 & 2.22 & $1.77^{\mathrm{B}}$ \\
\hline $\mathrm{I}$ & $70.2^{\mathrm{AB}}$ & 20.2 & $21.7^{\mathrm{B}}$ & $3.26^{\mathrm{B}}$ & 0.64 & 2.30 & $2.40^{\mathrm{A}}$ \\
II & $69.5^{\mathrm{B}}$ & 21.0 & $21.9^{\mathrm{AB}}$ & $3.22^{\mathrm{AB}}$ & 0.60 & 2.31 & $2.47^{\mathrm{A}}$ \\
III & $71.4^{\mathrm{A}}$ & 20.8 & $22.4^{\mathrm{AB}}$ & $3.02^{\mathrm{A}}$ & 0.59 & 2.25 & $2.36^{\mathrm{A}}$ \\
IV & 0.349 & 0.436 & 0.345 & 0.068 & 0.018 & 0.069 & 0.164 \\
SEM & & & & & &
\end{tabular}

$\mathrm{A}, \mathrm{B}-\mathrm{P}<0.01$ 
TABLE 4

Chemical composition of meat, \%

\begin{tabular}{|c|c|c|c|c|c|c|c|c|c|}
\hline \multirow{2}{*}{ Group } & \multirow{2}{*}{ Source of fat } & \multicolumn{2}{|c|}{ Water } & \multicolumn{2}{|c|}{ Protein } & \multicolumn{2}{|c|}{ Fat } & \multicolumn{2}{|c|}{ Ash } \\
\hline & & BM & $\mathrm{TM}$ & BM & TM & $\mathbf{B M}$ & TM & $\mathrm{BM}$ & TM \\
\hline I & Rape seeds "00" & 75.1 & 74.6 & 21.9 & 18.7 & $1.1^{\mathrm{b}}$ & $5.0^{\mathrm{a}}$ & $1.2^{\mathrm{a}}$ & 1.0 \\
\hline II & Lard & 74.8 & 74.5 & 22.0 & 18.7 & $1.4^{a}$ & $5.0^{\mathrm{a}}$ & $1.3^{\mathrm{b}}$ & 1.0 \\
\hline III & By-product fat & 75.3 & 74.5 & 21.7 & 18.2 & $1.4^{a}$ & $5.2^{\mathrm{a}}$ & $1.2^{\mathrm{a}}$ & 1.0 \\
\hline IV & Sunflower fat & 75.3 & 74.3 & 22.1 & 18.5 & $0.6^{\mathrm{w}}$ & $5.7^{\mathrm{b}}$ & $1.2^{\mathrm{a}}$ & 1.0 \\
\hline & SEM & 1.536 & 1.525 & 0.449 & 0.380 & 0.024 & 0.110 & 0.025 & 0.020 \\
\hline
\end{tabular}

BM - breast muscle; TM - thigh muscle

a, b, c $-\mathrm{P}<0.05$

The composition of the feed mixtures (Table 4) had no effect on the water and protein content of muscles. Similarly, Blanch and Grashorn (1995) did not find differences in the dry matter, protein, ether extract or ash contents of thigh and breast muscles of chickens fed mixtures containing soyabean, sunflower or linseed oil or lard as the source of energy. These authors reported that the amount of protein in the breast and thigh muscles was similar and averaged 24.8 and $24.2 \%$, respectively. In contrast, our earlier studies have shown that breast muscle contains an average of $3.0 \%$ more crude protein than thigh muscle (Świerczewska et al. 1991; Smolińska et al., 1994).

The percentage of fat in the breast muscle of chickens fed lard and by-product fat containing diets was the same $(1.4 \%)$. A lower content of this fat $(\mathrm{P}<0.05)$ was found in the breast muscles of broilers fed diet containing sunflower oil and rape seeds ( 0.6 and $1.1 \%$, respectively).

The physical and chemical properties of the meat (Table 5), i.e. water holding capacity, thermal leakage, and pigment content depended $(P<0.05)$ on the feed

TABLE 5

Physical and chemical properties of meat

\begin{tabular}{|c|c|c|c|c|c|c|c|c|c|}
\hline \multirow[t]{2}{*}{ Group } & \multirow[t]{2}{*}{ Source of fat } & \multicolumn{2}{|c|}{$\mathrm{pH}$} & \multicolumn{2}{|c|}{$\begin{array}{l}\text { Water holding } \\
\text { Capacity, } \%\end{array}$} & \multicolumn{2}{|c|}{$\begin{array}{c}\text { Thermal leakage } \\
\%\end{array}$} & \multicolumn{2}{|c|}{$\begin{array}{l}\text { Heme pigment } \\
\text { content, ppm }\end{array}$} \\
\hline & & BM & TM & BM & TM & BM & $\mathrm{TM}$ & BM & TM \\
\hline I & Rape seeds "00" & 5.8 & 6.4 & $34.6^{\mathrm{a}}$ & $86.5^{\mathrm{a}}$ & $2.8^{\mathrm{ac}}$ & $3.3^{a}$ & $38.3^{\mathrm{d}}$ & $49.2^{\mathrm{u}}$ \\
\hline II & Lard & 5.7 & 6.4 & $37.1^{b}$ & $92.5^{\mathrm{b}}$ & $1.4^{\mathrm{d}}$ & $1.5^{\mathrm{b}}$ & $36.6^{\mathrm{ab}}$ & $58.8^{b}$ \\
\hline III & By-product fat & 5.7 & 6.5 & $35.9^{\mathrm{ab}}$ & $100.0^{c}$ & $2.9^{\mathrm{a}}$ & $2.8^{\mathrm{c}}$ & $35.5^{\mathrm{a}}$ & $60.0^{\mathrm{b}}$ \\
\hline IV & Sunflower fat & 5.8 & 6.5 & $32.3^{\mathrm{c}}$ & $89.2^{\mathrm{ab}}$ & $2.7^{\circ}$ & $2.9^{\mathrm{c}}$ & $37.4^{\mathrm{ab}}$ & $48.3^{\mathrm{a}}$ \\
\hline & SFM & 0.118 & 0.133 & 0.715 & 1.893 & 0.051 & 0.054 & 0.754 & 1.115 \\
\hline
\end{tabular}

BM - breast muscle

TM - thigh muscle

$\mathrm{a}, \mathrm{b}, \mathrm{c}-\mathrm{P}<0.05$ 
composition. The breast muscles of chickens fed the rape seeds- and sunflower oil-containing diets had significantly lower water holding capacity than the meat from the chickens in the two other groups. Thermal leakage from breast and thigh muscles of chickens fed the lard-containing diet was lower than in the remaining groups ( 1.4 to $1.5 \%$ ). The addition of rape seeds to the feed caused a slight increase in the colour of breast meat in comparison with the other groups. This confirms the results of earlier studies by Świerczewska et al. (1991).

The $\mathrm{pH}$ of meat did not depend on the diet, but on the type of muscle: the $\mathrm{pH}$ was 0.7 units higher in thigh muscles and the water holding capacity was over twofold higher than in breast muscles. The lack of differences in $\mathrm{pH}$ among the broilcrs in the studied groups is probably attributable to the time lapse between slaughter and $\mathrm{pH}$ measurement. In this study, muscle $\mathrm{pH}$ was determined $24 \mathrm{~h}$ after slaughter. According to Gardzielewska (1993), the pH is highest in the first minutes after slaughter, and declines with time, with the differences ranging from 7.05 (after $1 \mathrm{~min}$ ) to 5.79 (after $30 \mathrm{~min}$ ).

TABLE 6

Results of sensory analysis of bouillon and meat, 5 degrec scoring system (5-the best)

\begin{tabular}{|c|c|c|c|c|c|c|c|}
\hline \multirow{2}{*}{ Group } & \multirow{2}{*}{ Source of fat } & \multicolumn{3}{|c|}{ Bouillon } & \multicolumn{3}{|c|}{ Meat } \\
\hline & & clarity & Ilavour & taste & flavour & taste & consistency \\
\hline I & Rape seeds "00" & $3.6^{a}$ & $3.8^{a}$ & $3.9^{\mathrm{a}}$ & 4.0 & 4.0 & $3.8^{\mathrm{a}}$ \\
\hline II & Lard & $4.4^{\mathrm{b}}$ & $4.3^{6}$ & $4.6^{b}$ & 4.1 & 4.3 & $4.3^{\mathrm{b}}$ \\
\hline III & By-product fat & $3.6^{\mathrm{a}}$ & $3.9^{2}$ & $4.3^{\mathrm{b}}$ & 4.1 & 4.1 & $4.2^{b}$ \\
\hline \multirow[t]{2}{*}{ IV } & Sunflower fat & $3.7^{\mathrm{a}}$ & $3.9^{\mathrm{a}}$ & $3.9^{a}$ & 4.0 & 4.3 & $4.5^{\mathrm{b}}$ \\
\hline & SE.M & 0.129 & 0.134 & 0.141 & 0.137 & 0.141 & 0.141 \\
\hline
\end{tabular}

a, $\mathrm{b}-\mathrm{P}<0.05$

The results of taste cvaluation (Table 6) of chicken bouillon showed several point differences in clarity, taste and flavour, depending on the type of diet. The scores for all three evaluated parametcrs of bouillon prepared from the meat of chickens fed the lard-containing diet were significantly higher in comparison with the bouillon of meat from other groups. In terms of taste and flavour, the tested meat did nol differ significantly. The consistency of meat from chickens fed the lard-, by-product fal- or sunflower oil-containing mixtures did not differ significantly. The addition of rape seeds caused a significant deterioration in meat consistency $(\mathrm{P}<0.01)$. The amount of fat added to the feed was rather low, which can explain the lack of organoleptic differences in the laste tests. Gardzielewska et al. (1992) using 12\% rape seeds or $18 \%$ rapeseed meal did not find any effect of these feeds on the desirable qualities of breast meat and broth aroma, but rape seed products negatively affected the taste of thigh meat. 
Cholesterol content in muscles, $\mathrm{mg} / 100 \mathrm{~g}$

\begin{tabular}{llcc}
\hline \multirow{2}{*}{ Group } & Source of fal & \multicolumn{2}{c}{ Muscles } \\
\cline { 3 - 4 } & & brcast & thigh \\
\hline I & Rape seeds "00" & 55.7 & $79.3^{\text {a }}$ \\
II & Lard & 56.0 & $79.4^{\text {a }}$ \\
III & By-product fat & 56.2 & $74.7^{\text {ab }}$ \\
IV & Sunflower fat & 52.9 & $72.5^{\text {b }}$ \\
& SEM & 1.129 & 1.555 \\
\hline
\end{tabular}

$\mathrm{a}, \mathrm{b}-\mathrm{P}<0.05$

The cholesterol content (Table 7) in the breast muscles of chickens fed diets with various fats did not differ significantly, but a significantly lower content of cholesterol $(\mathrm{P}<0.05)$ was found in the thigh muscles of chickens given the sunflower oil-containing feed $(72.5 \mathrm{mg} / 100 \mathrm{~g}$ tissue). The thigh muscles of chickens fed the diets supplemented with rape seeds and lard had the same cholesterol contents (79.3 and $79.4 \mathrm{mg}$ cholesterol/100 g tissue). Blanch et al. (1995) obtained different results: diets containing sunflower oil significantly raised the cholesterol content $(82.07 \mathrm{mg} / 100 \mathrm{~g}$ tissue) in comparison with animal fat, soyabean, rape seed or linseed oil. Hood (1991) found a higher cholesterol level in meat of quails fed beef tallow-supplemented diets, and a lower level in the quails feed sunflower, linseed or tuna fish oil in the diet. McIntosh and Oakeufull (1990) and Świerczewska et al. (1995) demonstrated a significant effect of the type of feed on thigh muscle cholesterol content, when comparing feeds containing oats, barlcy and rape seeds.

The fatty acid composition of the intramuscular fat of the breast and thigh muscles (Table 8) differed significantly $(P<0.05)$ depending on the feed composition. The addition of rape seeds or sunflower oil decreased the proportion of saturated fatty acids in total fatty acids. Conversely, the addition of lard increased their proportion in both types of muscle. Rape seed had a favourable effect on the composition of polyunsaturated fatty acids, increasing the proportion of linolenic and linoleic acids. Fecding a mixture to which lard, by-product fat or sunflower oil had been added did not change the percentage contents of these two acids in the overall composition of unsaturated fats in intramuscular fat. Many authors have pointed to the favourable effects of rape seed on the composition of unsaturated fatty acids (Hulan, 1984; Nwokolo and Sim, 1989; Lceson and Summers, 1991; Ajuyah et al., 1991, 1993).

Abdominal fat pad of chickens fed feeds containing sunflower oil or rape seeds (Table 9) contained morc unsaturated $(68.0 \%)$ and less saturated fatty acids $(32.0 \%)$ and had a lower melting temperature than the fat of chickens fed diets with lard $(64.5 \%$ unsaturated fatty acids and $35.5 \%$ saturated fatty acids, 


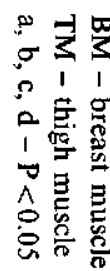

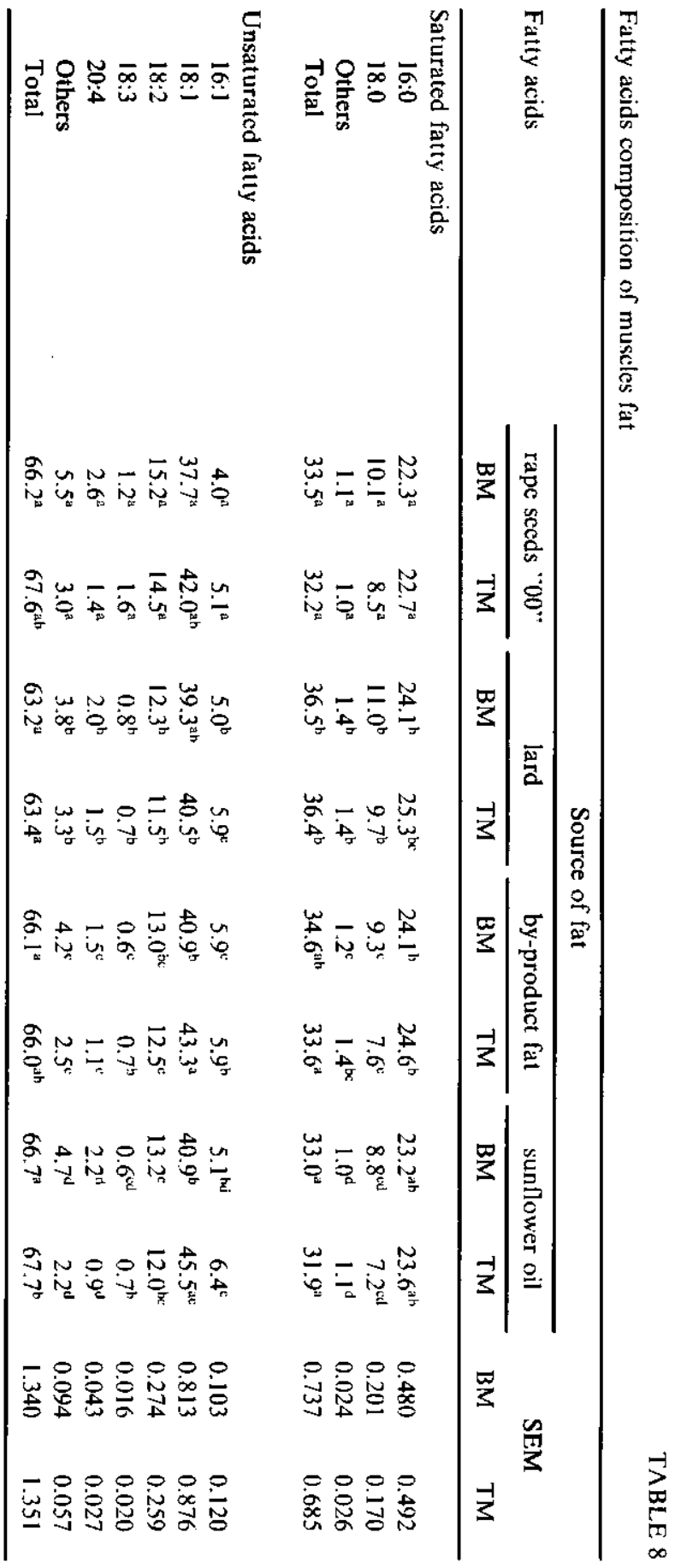




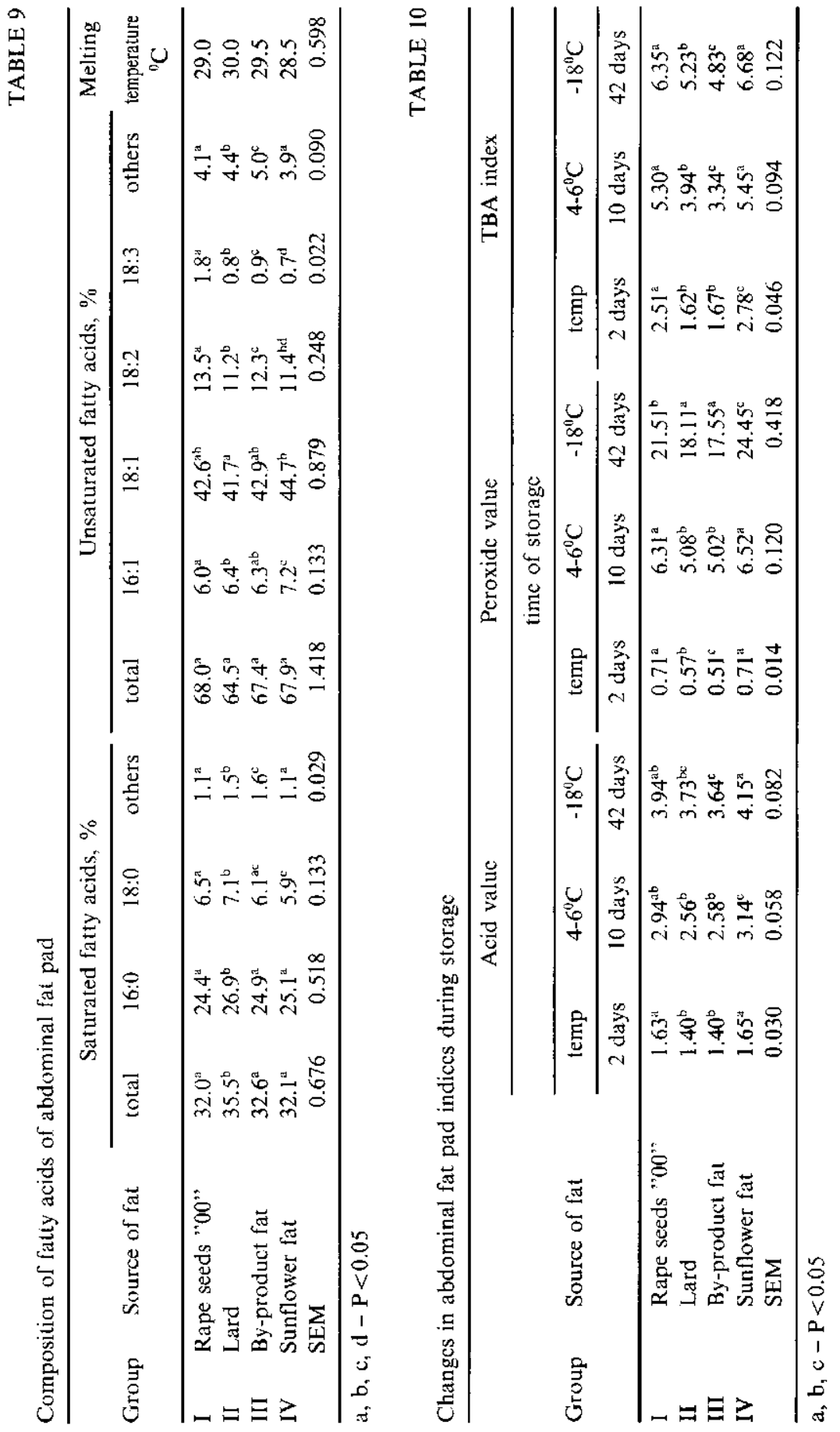


respectively). The acid value and peroxide value and the TBA index were also higher than in the fat of chickens fed diets with lard and by-product fat (Table 10). These fats underwent hydrolytic and oxidative processes faster during refrigeration and freczing.

\section{CONCLUSIONS}

Among the studied fats, a four percent addition of lard to the feed mixture significantly increased the body weight of broilers during 7 wecks of fattening as compared with by-product fat, sunflower oil or whole rape seeds, while the dressing percentage was the best in the group receiving sunflower oil.

The type of fat added to isonitrogenous and isoenergetic diets did not affect the chemical composition of the meat. The addition of lard increased the water holding capacity of meat, and decreased thermal leakage, the addition of sunflower oil decreased the cholesterol content, while the addition of rape seeds raised the linolenic and linoleic acid contents in the breast and thigh muscles.

\section{REFERENCES}

Adamski K., Gornowicz E., 1993. The effect of fats added to rations on the production indexes during growing and after slaughter of broiler chickens (in Polish). Zesz. Nauk. PTZ, Poultry breeding, No 8, 194-200

Ajuyah A.O., Lee K.H., Hardin R.T., Sim J.S., 1791. Changes in the yield and the fatty acid composition of wholc carcass and seleted meat portions of broiler chickens fed full-fat oil seeds. Poultry Sci. 70, 2304-2314

Ajuyah A.O., Hardin R.T., Sim J.S., 1993. Studies on canola secd in turkey grower diet: Fffects on omega- 3 fatty acid composition of breast mcat, breast skin and selected organs. Can. J. Anim. Sci.73, 177-181

Barylko-Pikelna N., Iwańska W., Jacórzyński B., 1973. The interaction between chemo-physic traits of protein substitutes and their technology usefulness (in Polish). Gosp. miçsna, 25 (8), 26

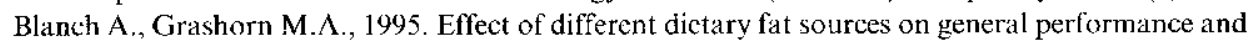
carcass yield in broiler chickens. Proceedings of the XII European Symposium on the Quality of Pouitry Meat, Zaragoza (Spain). pp. 71-75

Blanch A., López-Ferrer S., Barroeta A.C., Grashorn M.A., 1995. Effect of different dictary fat sources on cholesterol content in tissues of broiler chickens. Comparison of two methodologies. Proceedings of the XII European Symposium on the Quality of Poultry Meal, Zaragoza (Spain), pp. 453-459

Farrell D.J., 1978. Efficiency of utilisation by growing chickens of the energy of dietary fat and oil. Brit. Poultry Sci. 19, 105-109

Gardzielewska J., Kortz J., Uziębło L., Tarasewicz Z.. Karamucki T., 1992. The effect of leeding triticale and rape seed products on sensory characteristics of broiler meat. J. $\Lambda$ nim. Feed Sci. 1. $59-63$

Gardziclewska J., 1993. Dynamics of pH in breast muscles of broilcrs. $11^{\text {th }}$ Europcan Symposium on the Quality of Poultry Meat, Tours (France), pp. 251-255 
Hood R.L.. 1991. Effects of dietary fats on hepatic cholesterol synthesis in Japanese Quail. Poultry Sci. $70,1848-1850$

Hornsey H.C., 1956. The colour of cooked cured pork. J. Sci. Food Agric. 7. 534

Hulan H.W., Proudfool F.G. Nash D.M., 1984. The effects of different dietary fat sources on general performance and carcass fatty acid composition of broiler chickens. Poultry Sci. 63, 324-332

Ketels E., Groote De G., 1987. Effects of fat source and level of fat inclusion on the utilization of fatty acids in broiler dicts. Arch. Geflügelk. 51, 27-32

Lesson S., Summers J.D.. 1991. Commercial Poultry Nutrition, Guelgh, Canada

McIntosh G.II., Oakeufull D., 1990. Possible health benefits from barley grain. Chemistry in Australia, pp. 294-296

Niemiec J., Świcrczewska E., Stçpińska M., Ricdel J., 1996. Effect of different fat addition in diet on broilers performance (in Polish). 7esz. Nauk. PTZ Poultry breeding, No 24, 137-142

Nwokolo E., Sim J., 1988. Barley and full-fat canola seed in broiler diets. Poultry Sci. 68, 1374-1380

Rutkowski A., Krygier K., 1979. Fat technology and analysis (in Polish). Warsaw Agricultural University Press

Smolińska T., Świcrezcwska E., Nicmicc J., Popicl A.K., 1994. The effects of interactions between chicken genotypes and nutrition on chemical composition and technological value of chicken meat. Proceedings of the $9^{\text {th }}$ Furopean Poultry Conference, Glasgow (UK), pp. 225-226

Świerczewska E., Niemiec J., Mroczek J., 1991. Influence of rapessed products on broiler performance and meat quality. Quality of Poultry Products. Spelderholt Centre for Poultry Rescarch and Information Services, Beckbergen (The Netherlands), pp. 347-352

Świerczewska E., Niemiec J., 1995. The levels of cholesterol and lipids in the liver and muscles of 7 week old males and females fed the leed containing rapeseed "00". Proceedings of the XII European Symposium on the Quality of Poultry Meat, Zaragoza (Spain), pp. 447-452

Villalbi. E., Barroeta A.C., Blanch A., Puchal F., 1993. Effect of dietary added fat in the yield of whole carcass and selected meat portions of two strains of broilcr chickens. Proceedings of the $11^{\text {th }}$ European Symposium on the Quality of Poultry Meat, Tours (France), pp. 44-51

Wierbicki E., Tiede M.G., Burrel R.C., 1962. Die Bestimmung der Fleischguellung als Methode zur Untersuchung der Wasserbindungskapazität von Muskelproteinen mit geringem Safthaltevermögen. Dic Fleischvirtschaft 14. 948

\section{STRESLCZENIE}

\section{Wyniki produkcyjne kurcząt brojlerów oraz jakość ich mięsa w zależności od rodzaju tluszczu dodanego do mieszanek}

1200 kurcząt rodu ISA Vedetta żywiono od 4 tygodnia życia czterema mies/ankami o podobnej zawartości białka i energii, do których dodano: $8,0 \%$ nasion rzepaku (I), 4,0\% smalcu (II), 5,5\% thuszczu technicznego (III) lub $3,5 \%$ oleju słonecznikowego (IV).

Kurczęta żywionc paszą zawicrającą smalec osią̧nç̧ły najwyższą masę ciała $(\boldsymbol{P}<0,01)$ i zużyły najmniej paszy na $\mathrm{I} \mathrm{kg}$ przyrostu w porównaniu z brojlerami z innych grup.

Zawartość cholesterolu w mięsie kurcząt otrzymujących olej słonecznikowy byla najmniejsza, a zawartość kwasu linolowego i linolenowego w mięsniach piersiowych i udowych była największa u kurcząt żywionych dietą zawierającą nasiona rzepaku. 